\title{
ANALISIS TATA KELOLA PERUSAHAAN, DAN NILAI PERUSAHAAN
}

\author{
Noviarti ${ }^{1}$, Yosi Stefhani ${ }^{2}$ \\ Universitas Satya Negara Indonesia \\ Noviarti.arif@gmail.com ${ }^{1}$ yosi.stefhani@yahoo.com²
}

\begin{tabular}{lcl}
\hline Received: & Accepted: & Published: \\
1 Januari 2022 & 15 Februari 2022 & 22 Februari 2022 \\
\hline
\end{tabular}

\begin{abstract}
ABSTRAK
Penelitian ini bertujuan mengetahui secara empiris pengaruh dewan komisaris independent, kepemilikan institusi dan tingkat hutang terhadap nilai perusahaan yang diproksikan dengan Tobins Q. sampel yang diguna 120 sampel dari 30 perusahaan Infrastruktur yang terdaftar di BEI untuk periode 2017 sampai dengan 2020 dan memenuhi kriteria. Metode penentuan sampel berdasarkan kriteria atau purposive sampling. Pengujian data menggunakan uji klasik, analisis regresi linear bergandan dan pengujian hipotesis secara simultan dan parsial serta uji determinasi. Hasil penelitian secara simultan Dewan Komisari Independen, Kepemilikan Institusi berpengaruh signifikan terhadap nilai perusahaan. Secara Parsial Kepemilikan Institusi berpengaruh signifikan terhadap nilai perusahaan sedangkan Dewan Komisaris independent dan Debt to Asset Rasio tidak berpengaruh terhadap nilai perusahaan.
\end{abstract}

Kata Kunci : Nilai Perusahaan, Dewan Komisaris Independen,Kepemilikan Institusi, Debt to Asset ratio

ABSTRACT
This study aims to find out empirically the effect of independent commissioners, institutional ownership and debt levels on firm value as proxied by Tobins Q. The sample used was 120 samples from 30 Infrastructure companies listed on the IDX for the period 2017 to 2020 and met the criteria. The method of determining the sample is based on criteria or purposive sampling. The data using the classical test, multiple linear regression analysis and hypothesis testing simultaneously and partially as well as a test of determination. The results of simultaneous research on the Independent Board of Commissioners, Institutional Ownership have a significant effect on firm value. Partially, Institutional Ownership has a significant effect on firm value, while the independent Board of Commissioners and Debt to Asset Ratio have no effect on firm value.

Keywords : firm value, independent board of commissioners, Institutional Ownership, debt to Total Asset ratio

\section{PENDAHULUAN}

Nilai perusahaan adalah persepsi dari investor terhadap perusahaan yang mempuyai keterkaitan dengan harga saham. Harga saham yang tinggi merupakan pencapaian bagi perusahaan dalam mengelola perusahaannya dengan baik. Dimana semakin tinggi nilai perusahaan semakin tinggi tingkat pengembalian kepada investor. Tata kelola perusahaan yang baik akan meningkatkan kepercayaan investor untuk membeli saham perusahaan. Karena investor mempunyai ekspektasi perusahaan yang dikelola dengan baik akan mempunyai kinerja keuangan yang baik sehingga berpotensi mendapat keuntungan yang tinggi dan akan minimbulkan minat investor yang tinggi juga untuk berinvestasi melalui saham perusahaan tersebut. Tingginya minat 
investasi dari investor dapat meninggkatkan harga saham perusahaan sehingga memberikan pengaruh positif terhadap nilai perusahaan. Nilai perusahaan merupakan pandangan investor terhadap prusahaan yang behubungan dengan kepercayaan bahwa perusahaan mempunyai kemampuan dalam memberikan return yang diharapkan investor ketika memutuskan untuk menginvestasikan dananya pada perusahaan yang bersangkutan. Harga saham yang tinggi menunjukan perusahaan mempunyai tata kelola yang baik, nilai perusahaan mengalami peningkatan sejalan dengan naiknya harga saham akibat transaksi perdagangan saham di pasar modal.

Tata Kelola yang baik merupakan dasar untuk menetapkan kebijakan yang digunakan untuk mengambil keputusan oleh perusahaan. Tata Kelola perusahaan yang baik akan memberikan dampak positif bagi kinerja perusahaan yang akan menaikkan nilai perusahaan. Corporate Govermance menjadi faktor penting bagi nilai perusahaan sebagai alat kontrol untuk menjaga keseimbangan antara kewajiban dan hak bagi pemegang saham, manager, kreditur, pemerintah, karyawan, dan stakeholder (Mukhtaruddin et al. 2014). Good Corporate Governance dapat memberikan perlindungan bagi kepentingan pemegang saham dan kreditur sebagai pemilik dana eksternal agar mendapatkan pengembalian investasi yang wajar, tepat efisien dan memastikan bahwa manajemen memperhatikan dengan baik kepentingan perusahaan. Kepemilikan saham secara institusi akan mendorong manajemen untuk meningkatkan nilai perusahaan.

Pada perusahaan Infrastruktur yang terdaftar di Bursa Efek Indonesia ditemukan beberapa fenomena masalah, dimana perusahaan mengalami penurunan nilai perusahaan pada tanun 2017 sampai dengan 2020. Pada PT.Wintermar Offshore Marine Tbk.(WINS), tahun 2017 nilai perusahaan 3,37 turun menjadi 3,5 tahun 2018, 3,22 tahun 2019. Dan PT Cikarang Listrindo(POWR) tahun 2018 nilai perusahaan 1,66, tahun 2019 turun menjadi 0,52. Sedangkan pada PT. Bukaka Teknik Utama (BUKK) nilai perusahaan tahun 2017 bernilai 1,72, tahun 2018 turun menjadi 1,96, dan tahun 2019 turun menjadi 1,26, terus turun ditahun 2020 menjadi 1,03. Masalah yang mempengaruhi nilai perusahaan pada ke tiga Perusahaan manufaktur yang terdaftar di BEI dapat dilihat sebagai berikut.

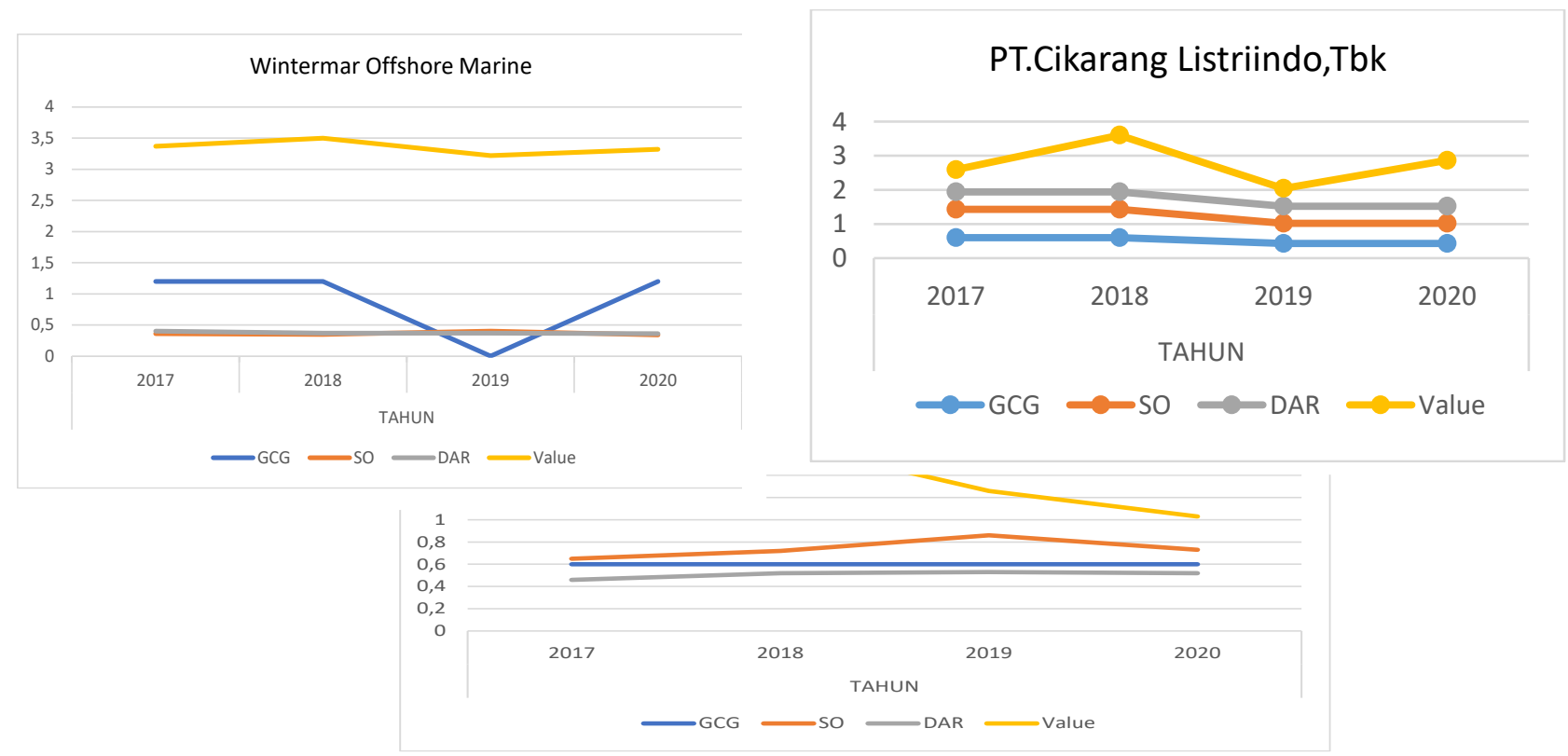

Gambar 1 Fenomena masalah 


\section{KAJIAN LITERATUR \\ Teori Keagenan}

Berdasarkan teori keagenan, asimetri informasi dan konflik keagenan antara manajer dan pemegang saham memberikan informasi yang diperlukan . Manajer dapat melakukan aktifitas yang dapat merugikan pemegang saham dan nilai perusahaan. Bataineh (2020) menjelaskan pengawasan oleh pemasok modal terhadap keputusan atau kebijaksanaan manajemen yang dapat digunakan untuk kepentingan mereka sendiri atas keputusan investasi yang tidak menguntungkan. Sehingga membantu mengurangi biaya keagenan yang timbul dari konflik kepentingan antara manajemen dan pemegang saham, dan menempatkan manajemen dibawah pengawasan pemasok modal.

\section{Nilai Perusahaan}

Nilai perusahaan merupakan harga yang bersedia dibayar oleh investor pada saat membeli saham perusahaan tersebut. Perusahaan yang mempunyai nilai tinggi menunjukan perusahaan dalam kondisi yang baik. Rahayu (2018), Nilai perusahaan adalah suatu kondisi tertentu yang telah dicapai perusahaan dan tercermin dari harga pasar saham perusahaan tersebut. Houston (2016), nilai perusahaan dilihat dari maksimalisasi kekayaan pemegang saham untuk memaksimumkan harga saham perusahaan.

Faktor yang mempengaruhi nilai perusahaan diantaranya:

1. Penerapan Good Corporate Governance (Tata Kelola Perusahaan yang Baik)

Tata Kelola perusahaan yang baik merupakan sistim mengawasi dan mengelola proses pengendalian usaha yang dilaksanakan secara berkelanjutan guna menaikan nilai perusahaan dan bentuk pertanggung jawaban kepada shareholder dengan tidak mengabaikan stackholder yang meliputi karyawan, kreditur dan masyarakat. Riska franita (2018:10)

\section{Share Ownership}

Share Ownership (struktur kepemilikan saham) merupakan struktur atau susunan kepemilikan dari pemegang saham atau stakeholder yang dapat dikatakan memiliki suatu perusahaan tertentu sesuai dengan seberapa banyak lembar saham yang ia miliki

3. Debt ratio (rasio hutang)

Rasio hutang mengukur persentase besarnya dana yang berasal dari hutang hutang ini termasuk semua hutang yang dimiliki perusahaan baik jangka pendek maupun hutang jangka panjang.

\section{Kerangka Teoritis \\ Dewan komisaris Independen terhadap Nilai Perusahaan}

Dewan komisaris Independen bertanggung jawab dan mempunyai wewenang untuk mengawasi Tindakan manajemen dan menasehati jika dianggap perlu oleh dewan komisaris. Jumlah dewan komisaris independen yang semakin banyak menunjukan bahwa dewan komisaris independen melakukan fungsinya sebagai pengawas dan koordinasi didalam perusahaan semakin baik. Oleh karena itu dapat dinyatakan bahwa Dewan komisari mempunyai peranan yang sangat penting dalam tata Kelola perusahaan dengan baik atau disebut juga Goood Corporate Governance. Penerapan tata kelola perusahaan akan memberikan pengaruh yang positif terhadap nilai perusahaan, karena Ketika perusahaan mengemukakan informasi tentang tata Kelola perusahaan yang baik, pemegang kepentingan akan memperoleh informasi yang dibutuhkan tentang perusahaan. Semakin banyak pengungkapan tata Kelola perusahaan yang baik yang dapat diberikan kepada pemegang kepentingan. 
Penelitian yang telah dilakukan oleh Yunita dan Prayitno (2019), Wahyuni (2018) menyatakan ukuran dewan komisaris berpengaruh positif dan signifikan terhadap nilai perusahaan. Sedangkan Penelitian Yohendra dan Susanti (2019), dewan komisaris tidak berpengaruh signifikan terhadap nilai perusahaan. Berdasarkan kerangka teoritis dan peneliti terdahulu maka rumusan hipotesis untuk penelitian sebagai berikut:

\section{H1 : Dewan Komisaris Independen berpengaruh positif terhadap Nilai Perusahaan}

\section{Kepemilikan Institusi terhadap Nilai Perusahaan}

Di banyak negara,Kepemilikan saham oleh lembaga atau institusi akan memberikan peran sangat penting mempengaruhi tata Kelola perusahaan dan secara partisipatif aktif menentukan kebijakan dividen perusahaan serta akan memberikan control yang baik terhadap manajemen suatu perusahaan yang dapat mengurangi biaya agensi dan dapat memaksimumkan nilai perusahaan. Dan investor institusi akan mencegah Tindakan yang merugikan perusahaan dengan melakukan pengawasan yang kontinyu agar nilai perusahaan meningkat. Kepemilikan institusi mempunyai hubungan yang positif dan signifikan terhadap nilai perusahaan. Dan informasi tersebut digunakan untuk pengambilan keputusan yang berkualitas. Pemegang kepentingan cendrung tetap melakukan investasi diperusahaan jika informasi yang diterimanya berkualitas, dan keputusan yang dihasilkan akan lebih baik sehingga saham perusahaan akan diminati banyak investor di pasar modal yang berpotensi menaikan harga saham sehingga nilai perusahaan juga akan naik. Dari penelitian Yohendra dan Susanti, (2019) Kepemilikan Institusi tidak berpengaruh signifikan terhadap nilai perusahaan.

Berdasarkan kerangka teori dan hasil penelitian sebelumnya maka rumusan hipotesis penelitian sebagai berikut:

\section{H2 : Kepemilikan Institusi berpengaruh positif terhadap nilai perusahaan}

\section{Rasio Hutang terhadap Nilai Perusahaan}

Pembiayaan perusahaan dapat bersumber dari modal sendiri maupun dari hutang. Apabila penggunaan hutang yang tinggi untuk pembiayaan perusahaan maka beban yang ditanggung perusahaan akan tinggi sehingga dapat mengurangi keuntungan yang akan diperoleh perusahaan sehingga saham perusahaan tersebut kurang menarik bagi investor untuk membelinya. Semakin tingginya hutang akan berisiko perusahaan tidak mampu membayar hutang karena aset yang dimiliki tidak mencukupi untuk membayar hutang. Hutang yang tinggi dan risiko yang ditanggung perusahaan juga tinggi sehingga rendahnya minat investor terhadap saham perusahaan yang bersangkutan, akan berpotensi menurunkan harga saham. Harga saham yang terlalu rendah menyebabkan turunnya nilai perusahaan.

Hasil penelitian yang dilakukan Sukma (2021), Debt to Total Asset Ratio berpengaruh positif dan signifikan terhadap nilai perusahaan. Sedangkan penelitian Yustrianthe dan Mahmudah (2021), Debt to total asset Ratio tidak berpengaruh signifikan terhadap nilai perusahaan. Berdasarkan kerangka teori dan penelitian sebelumnya maka rumusan hipotesis penelitian sebagai berikut:

\section{H3 : Rasio Hutang terhadap Aktiva berpengaruh positif terhadap nilai perusahaan}




\section{Kerangka Berpikir}

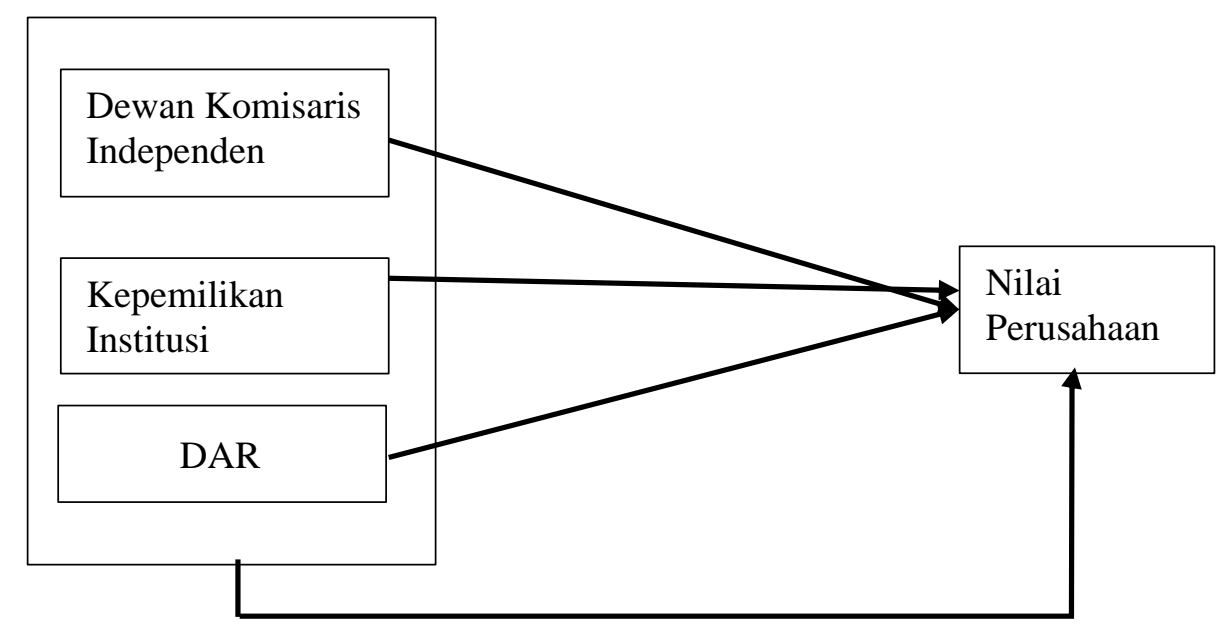

\section{METODE PENELITIAN}

Populasi penelitian adalah seluruh perusahaan infrastruktur yang terdaftar di Bursa Efek Indonesia selama periode pengamatan yaitu tahun 2017-2020. Data yang digunakan pada penelitian ini yaitu data sekunder. Data yang diperoleh secara tidak langsung yaitu melalui website:www. idx.co.id. Dan Teknik penentuan sampel dengan metode purposive sampling yaitu berdasarkan kriteria.

Penelitian ini merupakan penelitian kuantitatif kausalitas yang digunakan untuk mengetahui pengaruh beberapa variabel independent yaitu Dewan Komisaris Independen(x1),Kepemilikan Institusi(x2) dan RasioH utang(x3) terhadap variabel dependen dalam hal ini nilai perusahaan yang diukur dengan metode Tobins Q. Analisa data menggunakan Teknik Analisa data regresi linear berganda

Definisi Operasional Variabel mengemukakan tentang definisi variable dependen dan variable independent dan cara pengukurannya yang dapat dilihat pada ringkasan di table berikut:

Tabel 1. Definisi Operasional Variabel

\begin{tabular}{llll}
\hline No. & Variabel & Konsep Definisi & Indikator
\end{tabular}

\section{$1 \quad$ Variabel} Dependen:

$\begin{array}{llll}\text { Nilai } & \text { Jilai perusahaan merupakan } & \text { Tobins } Q=\frac{N V E+D}{B V E+D} & \text { Rasio } \\ \text { Perusahaa } & \text { suatu kondisi pencapaian } \\ \text { n: } & \text { perusahaan atas } \\ \text { tobins Q } & \begin{array}{l}\text { kepercayaan masyarakat } \\ \text { yang tercermin pada harga } \\ \text { saham perusahaan, }\end{array}\end{array}$




\begin{tabular}{|c|c|c|c|}
\hline & $(\mathbf{Y})$ & $\begin{array}{l}\text { dimana tingginya harga } \\
\text { saham meningkatkan nilai } \\
\text { perusahaan. } \\
\text { (Pardiastuti } \\
\text { et al.2020), } \\
\text { (wahyuni,2018) }\end{array}$ & \\
\hline 2. & $\begin{array}{l}\text { Variabel } \\
\text { Dependen }\end{array}$ & & \\
\hline & $\begin{array}{l}\text { Dewan } \\
\text { komisaris } \\
\text { Independen } \\
\text { (D.K.I) } \\
\text { X1 }\end{array}$ & 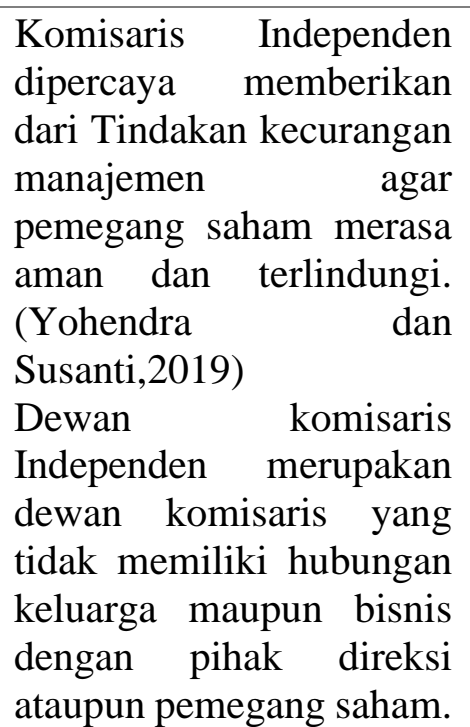 & $\begin{array}{l}\text { Komisaris Independen } \\
=\frac{\text { Jumlah Komisaris Independe Rasio }}{\text { Jumlah Anggota Komisaris }}\end{array}$ \\
\hline & $\begin{array}{l}\text { Kepemilika } \\
\text { n Institusi } \\
\text { (K.I) } \\
\text { X2 }\end{array}$ & $\begin{array}{l}\text { Kepemilikan Institusi } \\
\text { adalah kepemilikan saham } \\
\text { oleh pihak lembaga } \\
\text { seperti perusahaan } \\
\text { investasi,bank } \\
\text { dll.(Yohendra } \\
\text { dan Susanti,2019) }\end{array}$ & $\begin{array}{c}\text { Kepemilikan Institusi }= \\
\frac{\text { Jumlah Kepemilikan Saham Ins }}{\text { Jumlah Anggota Komisari: }}\end{array}$ \\
\hline & $\begin{array}{l}\text { Rasio } \\
\text { Hutang } \\
\text { (DAR) }\end{array}$ & $\begin{array}{l}\text { Hutang } \\
\text { informasi atau isyarat } \\
\text { mengenai aktiva dan modal } \\
\text { perusahaan karena hutang } \\
\text { yang tinggi r akan } \\
\text { meningkatkan keyakinan } \\
\text { akan aktiva dan modal } \\
\text { perusahaan. Hal ini } \\
\text { menunjukan bahwa semakin } \\
\text { tinggi DAR berarti semakin } \\
\text { besar jumlah modal yang } \\
\text { digunakan sebagai modal } \\
\text { investasi.(Dwipayana dan } \\
\text { Suharyana,2016) }\end{array}$ & $D A R=\frac{\text { Total Hutang }}{\text { Total Aktiva }}$ \\
\hline
\end{tabular}




\section{HASIL DAN PEMBAHASAN}

Perusahaan yang diteliti adalah perusahaan infrastruktur yan terdaftar di bursa efek Indonesia, dengan periode pengamatan dari tahun 2017 sampai dengan 2020. Berikut table kriteria penentuan sampel.

Tabel 2.

\section{Kriteria Penentuan Data Sampel}

\begin{tabular}{llcc}
\hline Kriteria Penentuan Sampel & $\begin{array}{c}\text { Jumlah } \\
\text { Perusahaan }\end{array}$ & \multicolumn{1}{c}{$\begin{array}{c}\text { Jumlah Data Sampel } \\
\text { Untuk 4 periode(2017-2020) }\end{array}$} \\
\cline { 3 - 4 } - & $\begin{array}{l}\text { Perusahaan Infrastruktur yang } \\
\text { terdaftar di BEI periode 2017-2020 }\end{array}$ & 57 & 228 \\
- & & \\
$\begin{array}{l}\text { Perusahaan Infrastruktur yang tidak } \\
\text { menerapkan GCG dan tidak memiliki } \\
\text { laporan keuangan lengkap }\end{array}$ & $(27)$ & (108)
\end{tabular}

\begin{tabular}{llllll}
\hline $\begin{array}{l}\text { Jumlah } \\
\text { kriteria }\end{array}$ & Perusahaan & yang memenuhi & $\mathbf{3 0}$ & 120 \\
\hline
\end{tabular}

Sumber: Data diolah 2021

Dari tabel kriteria penentuan data sampel, populasi penelitian seluruh perusahaan Infrastruktur yang terdaftar di BEI periode 2017-2020 sebanyak 57 perusahaan dan perusahaan yang tidak memnuhi kriteria 27 perusahaan. Perusahaan yang memenuhi kriteria untuk diteliti sebanyak 30 perusahaan untuk periode 4 tahun, atau sebanyak 120 data sampel.

Selanjutnya dilakukan analisis statistic deskriptif dengan tujuan untuk mendeskripsikan data dari variabel dependen. Analisa statistic deskriptif digunakan untuk menjelaskan data secara general dengan menghitung mean(rata-rata), nilai minimum,nilai maksimum dan Standar deviasi. (Sugiono, 2017:147). Barikut pada tabel statistik deskriptif dijelaskan hasil uji deskripsi data.

Tabel 3 Statistik deskriptif

\begin{tabular}{lcccc}
\hline & & \multicolumn{3}{c}{ Rata- } \\
& Minimum & Maksimum & rata & Std.Deviasi \\
\hline Corp.Value & .13 & 98.20 & 7.524 & 17.967 \\
D.K.I & .20 & 1.20 & .522 & .2003 \\
K.I & .05 & 38.10 & 1.01 & 3.456 \\
DAR & .13 & 51.00 & 2.964 & 6.074 \\
\hline
\end{tabular}

Sumber: Data diolah 2021

Dari hasil uji statistic deskriptif , nilai perusahaan secara rata-rata 7,524,nilai minimum 0,13 dan maksimum 98,20. Sedangkan hutang yang dimiliki perusahaan secara rata-rata 2,96 atau hampi 3kali dari aset yang dimiliki, dan masih ada perusahaan yang pembiayaan dari hutangnya rendah yaitu 0.13 sedangkan masimum 51.00. Kepemilikan institusi terendah atau minimal 0,05 dan maksimal 38.10 namun secara rata-rata masih rendah yaitu 1.01.

Sebelum dilakukan uji regresi linear berganda dan uji hipotesis dilakukan terlebih dahulu uji asumsi klasik, yang digunakan untuk memenuhi asumsi multivariat dalam statistik.Pengujian asumsi klasik dalam penelitian ini yaitu asumsi normalitas,multikolinearitas, uji heterokedastisitas dan uji auto korelasi. Dari hasil uji normalita data kolmogorof smirnov,data berdistribusi normal dengan hasil sig.0,129>0,05., dat juga tidak terjadi multikolenieritas,Dari 
hasil uji scatterplot tidak terdapat heteroskedastisitas pada model regresi dalam penelitian ini. Dari hasil uji autokorelasi terdapat asymp.sig. 2 tailet 0,714>0,05 artinya tidak terjadi autokorelasi antar residual.

\section{Tabel. 4. Hasil Pengujian Hipotesis}

\begin{tabular}{ccccc}
\hline Variabel & $\mathrm{B}$ & $\mathrm{T}$ & Ttabel & Sig. \\
\hline (Constant) & 1.919 & 5.780 & 1.9806 & .000 \\
DKI & -.021 & -2.30 & & .819 \\
K.I & -779 & 4.109 & & .000 \\
DAR & .147 & .748 & & .456 \\
R.Square & & & & .128 \\
Adjusted & & & & .106 \\
R.Square & & 5.685 & 2.68 & $.001^{\mathrm{b}}$ \\
\hline F & & &
\end{tabular}

\section{Sumber : Data diolah}

Dari tabel .. dapat dapat ditentukan persamaan regresi berganda untuk melihat yang mempengaruhi nilai perusahaan. Persamaan regresi sebagai berikut:

$\mathrm{Y}=1.919-0,21 \mathrm{CG}-779 \mathrm{KI}+147 \mathrm{DAR}$

Dari persamaan (1) dapat dijelaskan bahwa jika tidak terdapat variabel tata Kelola perusahaan, kepemilikan institusi dan hutang maka nilai perusahaan hanya sebesar 1,919. Dan jika tata Kelola perusahaan tetap senilai satu satuan maka nilai perusahaan akan turun sebesar 0,21. Jika komisaris Independen tetap tidak berubah maka nilai perusahaan akan turun senilai 779. Dan apabila hutang bertambah sebesar satu satuan maka nilai perusahaan akan naik sebesar 147 .

Hasil uji simultan diperoleh hasil uji Fhitung 5,685 dan hasil $F$ tabel yaitu 2,68, yang artinya nilai Fhitung $>$ Ftabel danSig.0,001<0,005 menunjukan secara keseluruhan terdapat pengaruh D.K.I ,KI dan DAR secara positif dan signifikan.

Untuk uji secara parsial Dewan Komisaris Independen tidak terdapat pengaruh signifikan terhadap nilai perusahaan, Berdasarkan hasil uji hipotesis dimana t hitung $-2,30<\mathrm{t}$ tabel 1,9806 dan sig 0,819.>0,05. Hasil penelitian ini menunjukan hipotesis $\mathrm{Ha}_{1}$ ditolak, hasil ini menunjukan dewan komisaris independen belum maksimal dalam memberikan pengawasan sehingga tidak berpengaruh terhadap nilai perusahaan. Jumlah dewan komisaris independen tidak dapat memberikan kontribusi yang maksimal dalam mengawasi Tindakan dan keputusan manajer perusahaan. Hasil penelitian ini sama dengan hasil penelitian Yohendra dan Susanti(2019),dan Debby et al.(2014).yang mengungkapkan dewan komisaris independent kurang efektif menjalankan tugasnya dalam mengawasi Tindakan manajemen.

Hasil uji hipotesis kepemilikan institusi menunjukan hasil t hitung 4,109 > T tabel 1.9806 dan Sig .000.> 0,05 artinya Hipotesis $\mathrm{Ha}_{2}$ diterima artinya terdapat pengaruh Kepemilikan Institusi secara signifikan terhadap Nilai perusahaan. Hasil penelitian ini menunjukan kepemilikan institusi mendominasi dalam melakukan pengawasan terhadap Tindakan dan keputusankeputusan manajemen dan kinerja manajemen. Dan apabila Kepemilikan Institusi yang kurang efektif akan menyebabkan nilai perusahaan menurun, Jika kepemilikan institusi mengawasi dengan baik maka kinerja perusahaan akan baik yang akan meningkatkan nilai perusahaan. Hasil penelitian ini tidak sejalan dengan penelitian Bernanddhi dan Muid,(2014), Yohendra dan Susanti(2019) yang menyatakan Kepemilikan isntitusi tidak berpengaruh signifikat terhadap nilai perusahaan. 
Untuk pengujian hipotesis tingkat hutang (DAR) terhadap nilai perusahaan diperoleh hasil thitung 0,748 < t tabel 1,9806 dan Sig.0,456 >0,05 artinya Debt to total asset Ratio tidak terdapat pengaruh signifikan terhadap nilai perusahaan. Hal ini menunjukan bahwa hutang yang dimiliki perusahaan tidak memberikan pengaruh signifikan terhadap nilai perusahaan. Hutang memberikan informasi atau syarat mengenai aktiva dan modal perusahaan karena hutanga yang tinggi akan meningkatkan keyakinan investor akan aktiva dan modal perusahaan.Semakin tinggi modal perusahaan seharusnya dapat memaksimalkan kegiatan perusahaan dalam menghasikan keuntungan yang akan meningkatkan minat investor sehingga nilai perusahaan meningkat.Sedangkan penelitian yang berbeda hasilnya dilakukan oleh perdana (2010) dan Dwipayana dan Suharyana(2016).

Kontribusi pengaruh Dewan Komisaris Independen, kepemikan istitusi dan tingkat hutang sebesar $10,6 \%$. Hal ini menunjukan masih rendahnya kontribusi pengaruh dari variabel yang diteliti dan $84 \%$ dipengaruhi oleh variabel lain.

\section{SIMPULAN DAN SARAN}

Hasil uji simultan diperoleh hasil secara keseluruhan terdapat pengaruh D.K.I ,KI dan DAR secara positif dan signifikan. Pengujian secara parsial dewan komisaris independen belum maksimal dalam memberikan pengawasan sehingga tidak berpengaruh terhadap nilai perusahaan. Jumlah dewan komisaris independen tidak dapat memberikan kontribusi yang maksimal dalam mengawasi Tindakan dan keputusan manajer perusahaan. Terdapat pengaruh Kepemilikan Institusi secara signifikan terhadap Nilai perusahaan. Hasil penelitian ini menunjukan kepemilikan institusi mendominasi dalam melakukan pengawasan terhadap Tindakan dan keputusan-keputusan manajemen dan kinerja manajemen. Dan apabila Kepemilikan Institusi yang kurang efektif akan menyebabkan nilai perusahaan menurun, Jika kepemilikan institusi mengawasi dengan baik maka kinerja perusahaan akan baik yang akan meningkatkan nilai perusahaan.

Hutang yang dimiliki perusahaan tidak memberikan pengaruh signifikan terhadap nilai perusahaan. Hutang memberikan informasi atau syarat mengenai aktiva dan modal perusahaan karena hutanga yang tinggi akan meningkatkan keyakinan investor akan aktiva dan modal perusahaan.Semakin tinggi modal perusahaan seharusnya dapat memaksimalkan kegiatan perusahaan dalam menghasikan keuntungan yang akan meningkatkan minat investor sehingga nilai perusahaan meningkat. Rekomendasi atau saran yang dapat diberikan untuk peneliti yang akan datang dengan menambah variabel lain karena masih bayak variable lain yang dapat mempengaruhi nilai perusahaan.

\section{DAFTAR PUSTAKA}

Alkurdi,Amneh, hamad ,Amneh , Thneibat ,Hussam and Elmarzouky Mahmoud ,(2021).Ownership structure's effect on financial performance: An empirical analysis of Jordanian listed firms

Gozali, Imam. 2013. Aplikasi Analisis Multivariate Dengan Program IBM SPSS 21 Up Date PLS Regresi. Edisi 7. Semarang : Badan Penerbit.

Pardiastuti, Pratiwi , Samrotun ,Yuli Chomsatu, (2018) Faktor-Faktor yang Mempengaruhi 
Nilai Perusahaan pada Perusahaan Manufaktur Sektor Industri Barang Konsumsi yang Terdaftar di BEI Periode 2016-337-345

Wijoyo, A. (2018). Faktor-Faktor Yang Mempengaruhi Nilai Perusahaan Pada Perusahaan Property Dan Real Estate Di Bursa Efek Indonesia. Jurnal Ekonomi, 48- 61

Wahyuni,Fitri (2018). Nilai Perusahaan, Indeks Tata Kelola Perusahaan Dan Struktur Modal Lavenia, Cynthia, Yohendra ,Meinie Susanty Tata Kelola Perusahaan Dan Nilai Perusahaan Bahraini , Endri Endri , Sugeng Santoso , Leni Hartati , Sri Marti Pramudena (2021), Determinants of Firm Value: A Case Study of the Food and Beverage Sector of Indonesia Syintia

Ratih, I Dewa Ayu, I Gusti Ayu Eka Damayanthi, 2016. Kepemilikan Manajerial Dan Profitabilitas Pada Nilai perusahaan, Dengan Pengungkapan Tanggung Jawab Sosial Sebagai Variabel Pemoderasi. E-Jurnal Akuntansi Universitas Udayana, 14(2), 1510-1538.

Jo, H., \& Harjoto, M. (2011). Corporate Governance and Firm Value: The Impact of Corporate Social Responsibility. Journal of Business Ethics, 103(3), 351-383.

Suhartati, T., Warsini, S., \& Sixpria, N. (2011). Pengaruh Pengungkapan Tanggung Jawab Sosial dan Praktik Tata Kelola Perusahaan terhadap Nilai Perusahaan. Jurnal Ekonomi Dan Bisnis, 10(2), 95-105 